受賞記念講演 : 平成 12 年度研究功績賞

\title{
金属粉および磁性粉の圧縮成形・加工に関する研究
}

沖本 邦郎

摂南大学, 干 572-8508 寝屋川市池田中町 17-8.

\section{Study of Compaction and Forming of Metallic/Magnetic Powders}

\author{
Kunio Okimoto \\ Setsunan University, 17-8 Ikeda-nakamachi, Neyagawa 572-8508.
}

Received July 12, 2001

\section{SYNOPSIS}

This paper reviews the researches in powder forming which were carried out by the author. In the compaction and forming of metal powders, first a compaction criterion in a stress state such that $\sigma_{2}=\sigma_{3}$ was obtained; this gives a relation between principal stresses and density of the green compact. Next, by using the results obtained from the cold forgeability of sintered iron, a ductile fracture criterion for porous metals was proposed. The formation process of joint strength in the infiltration joining was made clear. Furthermore, rapidly solidifying superplastic powder was prepared by centrifugal atomization method.

In the forming processing of magnetic powders, meantime, a new type of composite magnetic material was fabricated by combination with electro-magnetic properties of ferrite powder and the superplastic properties of $\mathrm{Zn}-22 \mathrm{Al}$ alloyed powder. To improve the magnetic characteristics of the permanent magnets, orientation forming of magnetic powders mixed with a MIM binder was attempted and a new orientation forming process was proposed. Moreover, for the purpose of producing ferrite part with a complicate shape which has different alignment of the ferrite crystallites, the feasibility of combined sinter joining method was carried out. As another application of combined sinter joining, a stainless steel-permalloy composite was fabricated and the forming conditions to give sufficiently high joint strength to it were found.

\section{KEY WORDS}

Powder forming, powder compaction, metal powder, magnetic powder, infiltration joining, superplasticity, composite magnetic material, orientation forming, MIM binder, sinter joining

\section{1 緒言}

粉末冶金，鋳造，塑性加工のような金型を用いる加工法を 総称して素形材加工と呼ぶことがある．粉末冶金が素形材加 工に対して占める割合は鋳造や塑性加工に比へて少なく，国 内における 2000 年度の生産実績 (金額) は 7.7\% かし，粉末治金の成形プロセスによれば複雑な形状の部品を 製造することができ，金属組織の微細・均質化が可能で，材 料成分の組み合わせの自由度が大きいなどの特徵がある.そ のため, 粉末成形は素形材加工において次第に重要性を增し ている2).

本研究は，粉末治金における主要プロセスである原料粉の 製造, 粉体の圧縮成形, 焼結, 後加工(後処理)の内で, 粉体 の圧縮成形および後加工を材料加工学的な観点から検討した
ものである.粉末成形を解析的に取り扱った研究引もあるが， 粉末の成形挙動に及ほす要因が多いことを考虑して，本研究 では実験的に取り扱った. 研究の主な目的は, 金属粉と硬質 磁性粉 (永久磁石用磁性粉) を用いた粉末成形において，加工 プロセスを適正化することによって粉末成形体の高機能化・ 高性能化を図ることである．金属粉関連では簡易ラバープレ ス，成形・破壊条件式，焟結金属の延性破壊，溶浸接合およ び急冷凝固超塑性粉などについて研究した。一方, 硬質磁性 粉関連では超塑性金属粉複合磁性体や配向成形，焼結接合に よる機能性配向磁性体と複合材の作製などについて梌討を 行った. 今回, 研究功績賞を授与されたので，これを機会に， これまでの研究を取りまとめてみた。 


\section{2 金属粉の圧縮成形·加工}

1965 年に当時の通産省工業技術院九州工業技術試験所 (現 在, 産業技術総合研究所九州センター)に入り, 数年間は「超 音波振動を付加した塑性加工の研究4-8)」を行った. 1971年頃 から粉末成形に従事するようになり, 最初に手がけた研究 テーマがFig.1のような “簡易ラバープレス法》”である. 周 知のように，金型(密閉形)成形法で作製した粉末成形体は, 粉末とダイスとの摩擦のために密度分布が不均一になりやす く, この傾向は加圧方向に長尺になるほと顕著である. そこ で, Fig.1に示すダイス(2)の内側に配置した円筒状ゴム型(3)の 内部に粉末(4)を充てんし，ゴム型と粉末を同時に圧縮成形す れば摩擦を低隇させることができ，長尺物が得られるものと 考えた. 鉄粉を用いた実験の結果, Fig.2(a)で示すような高さ $\mathrm{H} /$ 直径 $\mathrm{D}=8.8$ の圧粉体をつくることができた. しかし, パン チと円筒状ゴムおよび粉末との摩擦条件によっては, Fig.2(b) のような圧粉体の高さ方向の中央部分における直径に比べて 両端面での直径が大きくなる, いわゆる “象の足” 現象が生 じた.この形状が主因で, 圧縮後の除荷過程で圧粉体か破壊 することが時々あった.この成形法では粉末の充てん密度が 大きく粉末を均一に充てんすることが重要であると判断され たので, 金型とゴム型を同時に振動して見掛け密度の状態か らできるだけタップ密度に近づけてから成形した. 後に開発 されたエアーレート充てん法 ${ }^{10}$ やエアータッピング法11)のエ 学的重要性を再認識する次第である.

さて，この簡易ラバープレス法の場合, 粉末は軸対称の応 力状態の下で固化される. ゴム型の厚さによって圧粉体に作 用する応力状態が変化し, 圧粉体密度はこの影響を受ける. しかし, 応力状態と密度との関係は不明であった.このよう な成形を行うに際しては, 粉末が固化成形されるときの一般 的な 3 主応力と密度との関係式, すなわち粉末の成形条件式

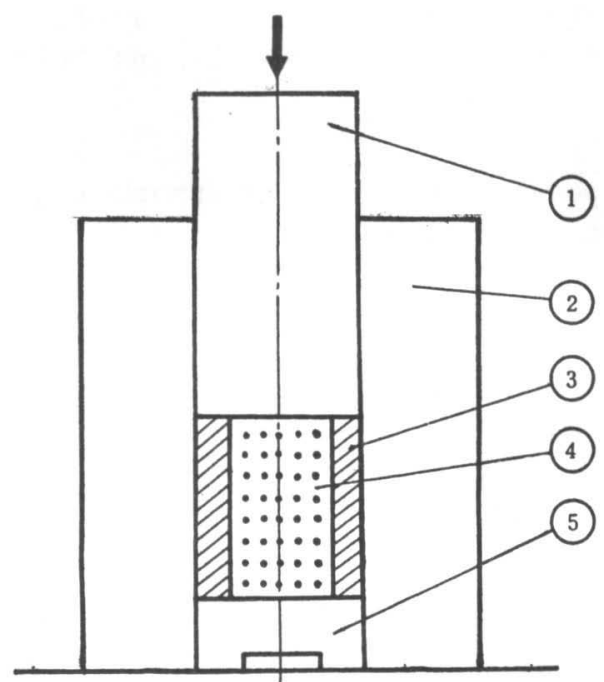

(1) Upper punch, (2) Die, (3) Rubber cylinder,

(4) Powder, (5) Lower punch

Fig.1 Schematic illustration of a simple rubber-press method.
について基礎的なことを理解しておくことが重要であると痛 感した. そこで, 当時, 焼結金属を塑性加工学的に取り扱っ ており, 顕著な業績をあげておられた京都大学の大矢根守哉 教授 (現在, 京都大学名誉教授)のところで, 約 1 年間, 研究 する機会を得た.

その期間中に軸対称成形の場合における粉末の成形条件式 と圧粉体の破壊について研究した. 成形条件式における材料 定数の求め方として, 金型成形における成形圧力 $\sigma_{1}$ と密度と

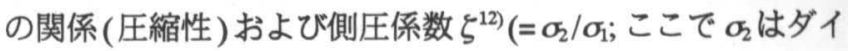
スに作用する側方向の応力)を用いる方法を提案し ${ }^{13)}$, 粉末成 形の現場において粉末特性を評価するための重要な物性値と されている “圧縮性”に，力学的な意義付けを行うことがで きた ${ }^{13}$. また, 銅圧粉体の破壊について研究し, 粉末の成形 条件式と破壞条件を統一的に表示することができた ${ }^{14)}$.

次に, 鉄系焼結体の延性破壊 ${ }^{15}$ について検討し，鉄系焼結 体の鍛造中における加工限界の予測や焼結鍛造品の延性を評 価するのに役立てることができた．また，金属焼結体の再圧 着1のにおいては, 鍛造過程において一旦生じたクラックが, その後の鈠造過程で押しつぶされて見掛け上は再圧着したよ うな状態になるが,このような過程を経て得られた鍛造品の 延性は, 鍛造中に全くクラックが生じなかったものに比べて 格段に劣っていることが分かった. そこで，再圧着体の延性 を向上させるために, 再圧着後に $1100^{\circ} \mathrm{C}$ 程度で熱処理を行っ たところ, クラックが生じなかった場合に比べてほとんどそ ん色の無い程度にまで鍛造性が回復した。

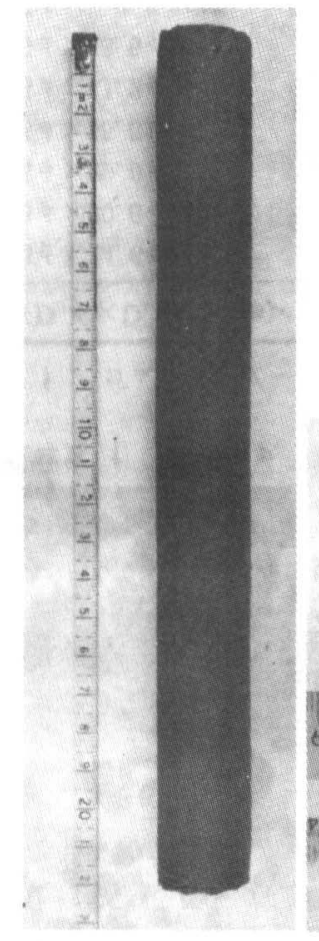

(a) Succeeded

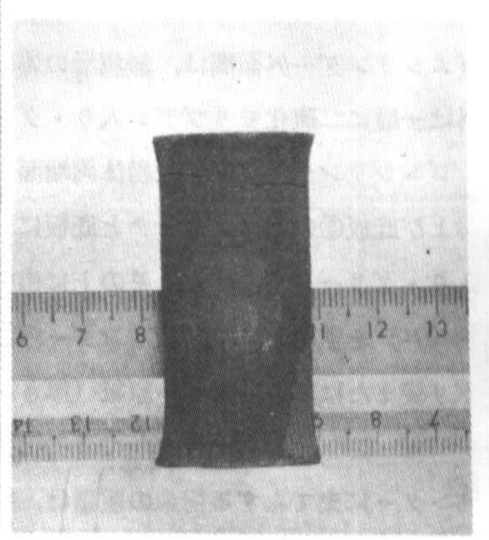

(b) Failed (Crack)
Fig.2 Appearance of green compacts fabricated from a simple rubber-press method. 


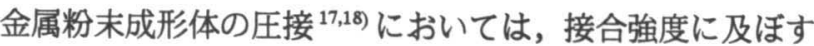
接合圧力, 接合時のクリアランス, 密度, 接合面の粗さおよ び接合温度の影響を調べ, 接合部の強度が非接合部と同等に なるための条件を明らかにした.一方, 金属粉末成形体の気 孔を積極的に活用する溶浸接合 ${ }^{19-22)}$ においては，摩擦圧接な どの場合と同様に, 衝撃值や延性は一体ものの溶浸体に比へ てやや劣っていた. しかし, 静的接合強度に関しては一体も のの溶浸体に匹敵する強度が得られ，接合と母材の強化を同 時に図ることができ，かつ接合部近傍の硬度分布は一体もの の場合とほとんど変わりなく, 本接合法の有効性が明らかと なった. また, 溶浸接合体の静的強度は, 複合材料における 混合則より予測することができた。

当時, 元の職場においては, 研究の重点分野が新素材関連 に移行しつつあった. そこで, これまでの研究を一段落とし $て^{23}$ ，粉末成形の分野における “(新)材料” と“加工” とい う内容で展開を図ることとし，超塑性急冷凝固粉の作製とそ の成形加エプロセスの適正化のテーマを取り上げた．

周知のように金属組織を微細・均質化すれば，高強度・高 勒性の材料をつくることができ, 場合によっては超塑性・形 状記憶のような機能性も発現する. 組織微細化の手段として は, 添加元素法, 急冷凝固法, メカニカルアロイング法など があるが, 著者らは急冷凝固法の一種である遠心力噴霧法に 注目し,Zn-22Al合金粉の作製とその成形体の変形特性につい て研究した ${ }^{24-29}$.

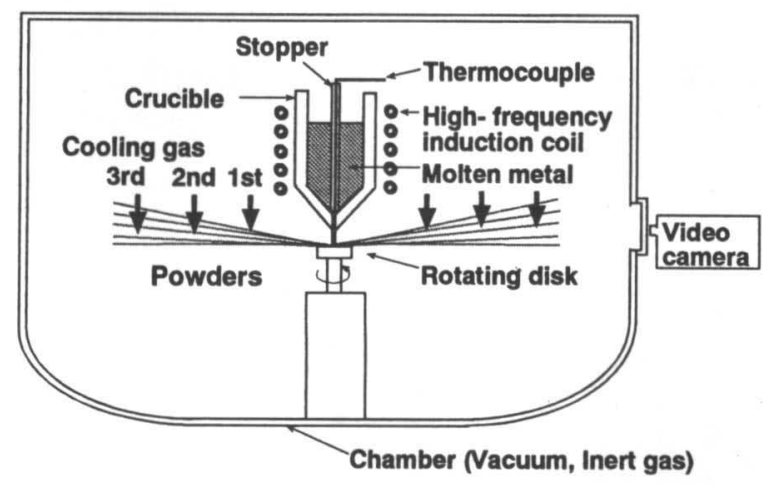

Fig.3 Schematic illustration of centrifugal atomization equipment.
Fig.3は設置した遠心力噴霧装置の概念図である.この装置 で急冷凝固粉を製造する場合の冷却速度は, $\mathrm{Al}-33 \mathrm{Cu}$ 合金粉 のラメラー間隔や $\mathrm{Al}-1 \% \mathrm{Si}$ 合金粉のデンドライトアーム間隔 の測定結果から, $10^{4} \sim 10^{5}{ }^{\circ} \mathrm{C} \cdot \mathrm{s}^{-1}$ のオーダー ${ }^{30)}$ と推定された. 本装置による研究を通じて, 遠心力噴霧法における粉末の収 率は回転円盤と溶解金属との濡れ性によって大幅に変化し, 収率を向上させるためには回転円盤表面に適切な溶着層 ${ }^{31-33)}$ を形成させなければならないことが判明した.

作製した Zn-22Al 合金粉の金属組織は Fig.4(c)のようであ る.この粉末を密閉金型で予備成形した後に $250^{\circ} \mathrm{C} て ゙$ 押出し 加工 (押出し比: 10) したものを引張り試験すると, Fig.5で示 すように伸びは最大で 1000\%に達し, 従来からの空気噴霧法 で作製した成形体の伸びが $300 \%$, 溶解鋳造材が $80 \%$ であるの に比べて, 格段に大きくなった.このように遠心力噴霧法が 超塑性材の製造手段として有効であることが確認できた. 遠 心力噴霧装置は, $\mathrm{Cu}-\mathrm{Al}-\mathrm{Ni}$ 系形状記憶合金粉など ${ }^{34,35)}$ を作製 するためにも使用された. その後, 共同研究者であった佐藤 富雄氏によって Al-Mn系および $\mathrm{Al}-\mathrm{Si}$ 系の急冷凝固合金粉 ${ }^{3036-39}$ への展開が図られた。

$\mathrm{Zn}-22 \mathrm{Al}$ 合金は超塑性を有するだけでなく, 拡散接合性, 電

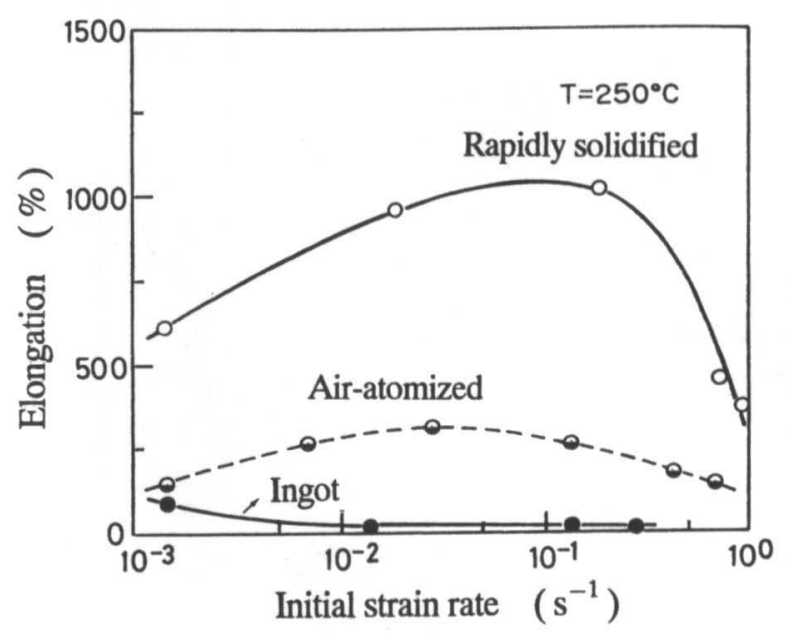

Fig.5 Elongation of compacts made from rapidly solidified $\mathrm{Zn}-22 \mathrm{Al}$ alloyed powders.

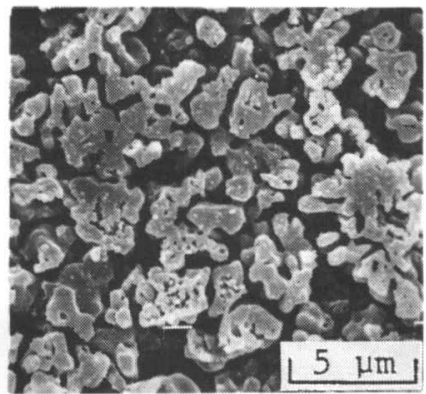

(a) Air-atomized

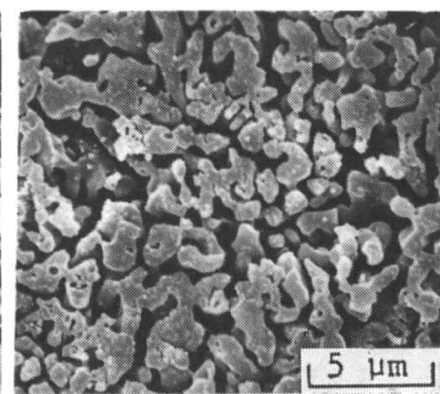

(b) Argon-atomized

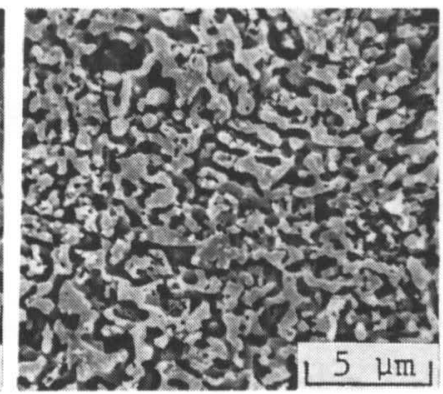

(c) Rapidly solidified

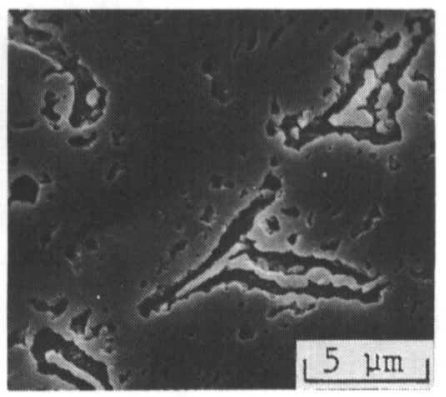

(d) Ingot

Fig.4 Microstructures of $\mathrm{Zn}-22 \mathrm{Al}$ alloyed powders and the ingot observed by SEM. 
磁波シールド性，制振性がすぐれていると言われている．そこ で,Zn-22A1合金粉と磁性粉から成る複合磁性体が作製できれ ば，磁性粉から硬磁性の場合には成形後の着磁姏理により永久磁 石となり，軟磁性粉の場合には周波数帯域の広い電磁波シ一 ルド材や制振材としての用途が期待できる.そこで, $\mathrm{Zn}-22 \mathrm{Al}$ 合金粉の応用例としてハードフェライト粉との複合化 $28,40-44)$ を手がけ，これを契機として磁性粉の配向成形の研究に至っ ている.

\section{3 磁性粉の成形加工}

\section{1 複合磁性体 (ボンド磁石)の磁気特性}

$\mathrm{Zn}-22 \mathrm{Al}$ 合金粉を用いた複合磁性体における Zn-22Al 合金 は，慣用の樹脂ボンド磁石やゴムボンド磁石におけるバイン ダー用のプラスチックやゴムの代替材料として使用したこと に相当する.Zn-22Al合金はプラスチックやゴムに比べて酎熱 性・耐候性がすぐれており，またプラスチックやゴムが一般 に絶縁性で一旦成形すると可塑性が無くなるのに対して，導 電性や再加工性などの金属性機能を有しているという特徵が ある。

製造工程は次のようである.Zn-22Al合金粉とハードフェラ イト粉を混合し,次に室温または $250^{\circ} \mathrm{C} て ゙$ 密閉金型成形し，得 られた成形体を着磁処理することにより複合磁性体とした ${ }^{42439}$. この成形プロセスで作製した複合磁性体の磁気特性(残留磁束

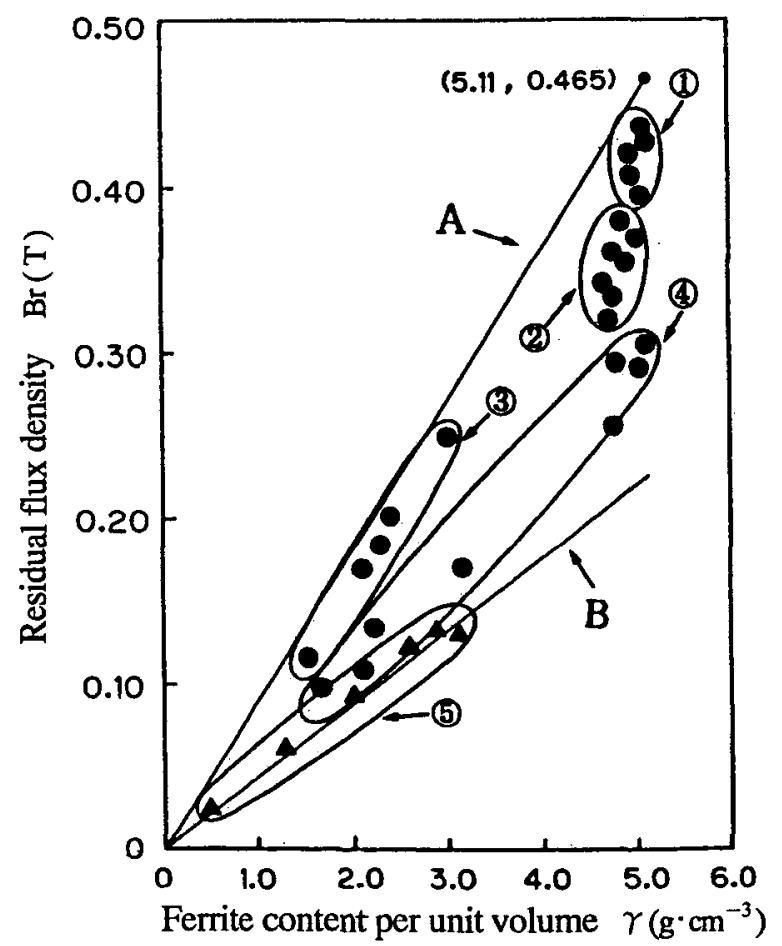

(1) magnetic forming, (2) rolling, (3) rolling of rubber magnet, (4) closed-die compaction, (5) closed-die compaction of isotropic powder

Fig.6 Relationship between residual flux density and ferrite content per unit volume of compacts.
密度 $\mathrm{B} r$ )を，成形体の単位体積当たりの磁性粉(フェライト) 重量 $\gamma^{*}$ )との関係で Fig.6の図中(5)(ム印)に示す. 図から明ら かなように, $\mathrm{B} r$ は成形圧力, 成形温度および粉末混合法に関 係なく，単位体積当たりの磁性粉重量 $y$ で整理することがで き, $\mathrm{B} r$ は $\gamma$ にほぼ比例する.したがって，磁気特性を向上さ せるためには $\gamma$ が大きくなるような成形条件を選んでやれば よい. Fig.6の(5)の場合, $\mathrm{Br}$ の最大は約0.14T(テスラ), すな わち約 $1400 \mathrm{G}$ である.

磁性体の磁気特性を更に向上させるためには，磁場配向 ${ }^{45-47}$ や機械的配向 ${ }^{47-49}$ (圧延や押出しのような塑性加工的手法)に よって磁性粉の磁化容易軸 (C軸) を並へ, 異方性を付与すれ ばよい.Sr-フェライト粉の配向が完全に達成され，かつ複合 磁性体の $\gamma$ が $\mathrm{Sr}$-フェライトの真密度である $5.11 \mathrm{~g}^{\circ} \mathrm{cm}^{-3}$ に到達 すればBrは0.465Tになるとされている。 そこで Fig.6におい て $\mathrm{B} r$ の理想的な最大値と原点を結ぶ直線を $\mathrm{A} て ゙$ 定義する. 図 中で直線 B は A の勾配の $1 / 2$ として引いたものである. 磁界 が作用しない状態の下で成形した実験結果(5)，直線 Bでほ ほ近似できる。

一方，配向成形した複合磁性体の場合には，磁気特性を単 位体積当たりの磁性粉重量 $\gamma$ で一意的に評価することができ ず, 磁性粉の配向状態により直線 $\mathrm{A}$ と B の間で磁気特性が変 化する. そのため $\gamma$ に対応する直線 $\mathrm{A}$ 上にできるだけ近づけ るように適切な成形加エプロセスを選定することが重要とな る.このように配向成形プロセスの適正化によって磁気特性 が約 2 倍向上することに磁性粉を配向成形することのおもし ろさと有用性がある。

3.2 複合磁性体 (ボンド磁石)における磁気特性の限度

Fig.7は，磁界がない状態で冷間金型成形した複合磁性体に

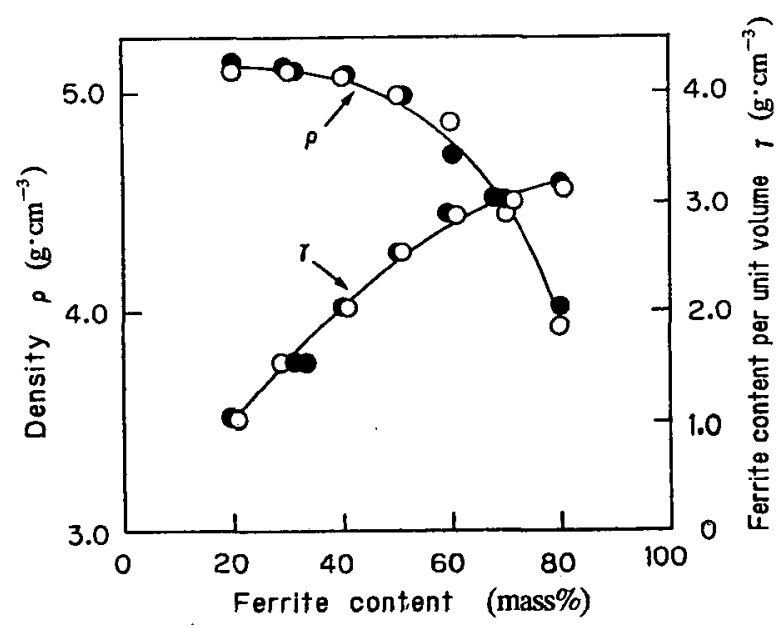

Fig.7 Effect of ferrite content on density and ferrite content per unit volume of compacts.

\footnotetext{
?) 単位体糟当たりの磁性粉 (フェライト) 重量 $\gamma=$ 䙓合磁性体の密度 $\mathrm{x}$ 磁性粉 の湜合割合

ここて，磁性粉の混合割合 $=[$ 磁性粉 $/($ 磁性粉 $+\mathrm{Zn}-22 \mathrm{Al}$ 合金粉 $)]$ mass\%
} 


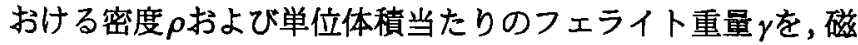
性粉の混合割合との関係で示したものである，図中の○と○ 印は鉻柄が異なるSr-フェライト粉を指している.図中には磁 性㸮の混合割合が 80 mass\%までを示したが，これ以上の状態 では成形体にラミネーションクラックが発生しやすく, $\rho$ と $\gamma$ を測定することが困難であった.100 mass\%の状態における $\gamma$ ，

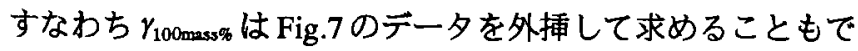
きるが, Fig.8に示すフェライト粉の冷間 “圧縮性” のテータ (○印)における最大値(飽和値)がこの值に相当するとみなせ る. Fig.8の○印のデータから明らかなように, 冷間圧縮成形 したフェライト圧粉体の密度はほほ $3.20 \mathrm{~g} \cdot \mathrm{cm}^{-3} て ゙$ 飽和し， フェライトの真密度 $\left(5.11 \mathrm{~g} \cdot \mathrm{cm}^{-3}\right)$ に対して $65 \%$ 程度に過ぎな い.ここで，粉末を均一球でモテル化した場合における見掛 け密度比(見掛け密度の相対密度表示)の理論値は菱面体配列 の 0.74 が最大で，最小は立方配列の $0.52^{50}$ である.実際の粉 末は粒子形状が不規則状であるので，前記の相対密度を低下 させる要因になり，その一方で粒度分布があるので，これは 相対密度を上げる要因になる.また圧縮成形の初期において は粉末粒子の再配列によって密度が向上するが，その後の過 程においてはフェライトのようなセラミック粉は塑性変形し ないので圧粉体密度はほとんど増加しない．これらの要因か 組み合わさり，圧粉体密度は Fig.8のようにほほ $3.20 \mathrm{~g} \cdot \mathrm{cm}^{-3}$, すなわち相対密度 0.65 の前後で的和する. 以上より，フェラ イト粉を用いた複合磁性体を冷間圧縮成形した場合における 磁気特性の最大值は, $\mathrm{Br}$ を例にとれば配向が完全になされた 場合 $\mathrm{Br} \leqq 0.465 \times\left(\gamma_{100 \mathrm{mass} \%} / 5.11\right) \mathrm{T}=0.465 \times(3.20 / 5.11)=0.29 \mathrm{~T}$, 無 配向の場合 $\mathrm{Br} \leqq(0.465 / 2) \times(3.20 / 5.11)=0.15 \mathrm{~T}$ であると判断さ れる.前者の0.29TはFig.6の図中(3)で示したゴムボンド磁石 の圧延配向成形 ${ }^{48)}$ における到達目標値である.

したがって複合磁性体のようなボンド磁石タイプのもので 焼結プロセスがない場合, その磁気特性は磁性粉の“圧縮性”

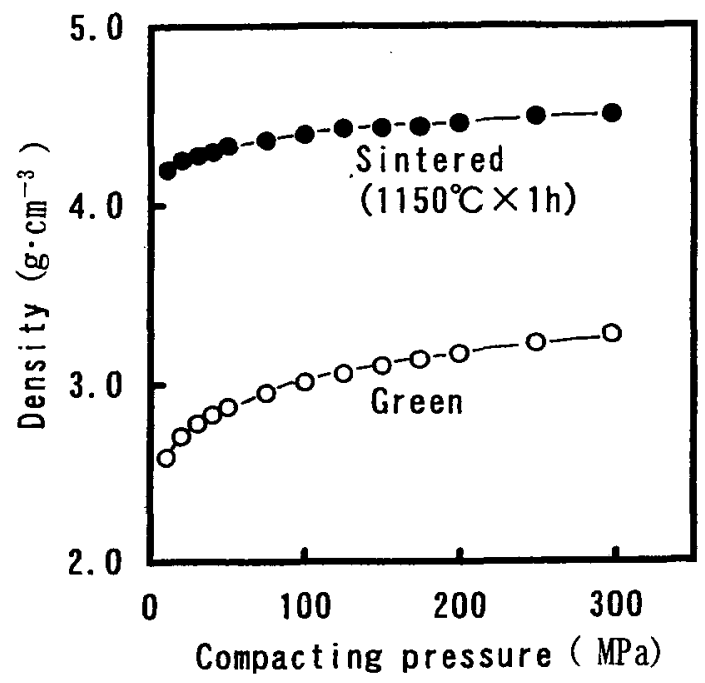

Fig.8 Relationship between green density of ferrite powder and compacting pressure at closed-die compaction.
により左右されることが分かる。そのため複合磁性体の磁気 特性を向上させるためには，“圧縮性”のよい磁性粉が望まし く,その一手段として粒度分布を持たせることが考えられる。 一方，磁性粉の粒子そのものの磁気特性に注目した場合，単 磁区臨界粒子径(フェライトの場合約 $1 \mu \mathrm{m}$ ) 以上のものでは磁 気特性が低下するので，この粒子径以下のものが望ましい. しかし，粒子径が小さくなると成形時のハンドリングなどが 一段と困難になる。したがって，粒度分布を与えることによ る成形体密度の向上と単磁区粒子の磁気特性との両立という 点において，ボンド磁石は成形上の難しさがある.

また，複合磁性体の機械的強度も考虑する必要がある．複 合磁性体の強度は $\mathrm{Zn}-22 \mathrm{Al}$ 合金粉を混合することにより向上 するが，その一方では Zn-22Al 合金粉の混合割合に応じて磁 気特性が低下する．そのため，できるだけ少ない $\mathrm{Zn}-22 \mathrm{Al}$ 合 金粉の使用により複合磁性体の強度が発揮されることが望ま しい.この点から $\mathrm{Zn}-22 \mathrm{Al}$ 合金粉と磁性粉の適合性が問題と なる、そこで，複合磁性体の強度に及ぼす粉末混合条件や成 形温度などの影響について検討した。その結果，成形温度が

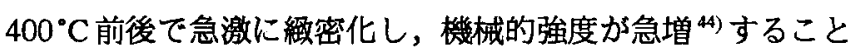
を見出した。

3.3 配向成形

(a) 焼結磁石 磁気特性を最も重要視する場合においては， 当然のことながら $\mathrm{Zn}-22 \mathrm{Al}$ 合金粉を用いない方がよい．この ような場合を対象として, 粉末射出成形(MIM) 用の熱分解性 バインダーを用いてハードフェライト粉を混練しておき，こ れを配向成形した後に脱バインダー・焼結してフェライト単 味の焼結体，すなわち焼結磁石とする方法について検討した. 配向成形の具体的手段としては，磁場成形 (磁界中配向成形) ${ }^{45}$ と圧延成形 ${ }^{49)}$ を行った(Fig.6の(1)と(2)). その結果, MIMバイ ンダーが極めて良好な配向剂として作用し，磁場成形では Fig.60図中(1)のように磁気特性のすぐれた焼結磁石が得られ た. MIMプロセスによる磁場成形は，水バインダーを用いる 従来からの磁場成形に比へて，小物で複雑形状の永久磁石を 製造するための手段として適していると思われる.

(b) 配向度 $\mathrm{B} r / \mathrm{J} s$ に及ぼす磁性粉の粉砕粒度と成形圧力 $\mathrm{Sr}$ フェライト磁性粉の配向度 $\mathrm{B} r / \mathrm{Js}$ に及ほす粉砕粒度と成形磁界

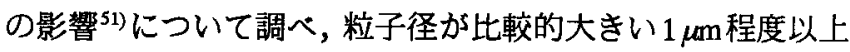
では $\mathrm{B} r / \mathrm{J} s$ は粒子径にほとんど依存しないが, $0.7 \mu \mathrm{m}$ 程度の微 粒子では $\mathrm{Br} / \mathrm{J} s$ の飽和值が小さいことを明らかにした。一方，

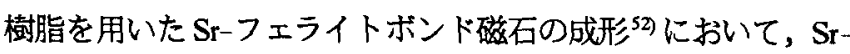
フェライト粉の保磁力の変化は金型成形(一軸加圧成形)と冷 間静水圧成形(CIP)では異なり，金型成形の方がその低下度合 いが大きいことを明らかにした.ただし,この実験の場合, 金 型成形ではSr-フェライト粉とエポキシ樹脂粉との混合粉を使 用したのに対して，CIP 成形では水バインダーを用いたスラ リー状のSr-フェライト粉を使用しており,粉末の使用環境が 同一でない，そのため，保磁力の低下度合いが異なった原因 は，成形法の相違によって磁性粉に作用する圧力形態が異な る(金型成形においてはせん断応力成分がある)ためであると 
は早急に結論付けることができない．この原因がどこにある かを究明することは，ボンド磁石の成形条件の適正化を図る に際して大変興味深い課題であると思われる。

(c)新しい配向成形プロセスの試み 現在の磁場成形の一般 的な方法は, 磁場配向プレス機を用いて, 配向と成形を一エ 程で行う方式である。この方法の場合, 磁場配向プレス機に 組み込まれた磁極間に成形用金型を配置するため成形できる 形状・寸法に制約があり, また大容量の磁界発生装置が必要 である. 生産性にも問題があると言われている.そこで，こ れらの問題点を解消することを目的として，慣用のプレス機 を用いて作製した成形体をプレス金型から取り出した後で配 向を行う方法に着目した ${ }^{53,54)}$.この場合, 成形によって一旦圧 密された磁性粉単味の成形体に磁界を印加しても成形体中の 磁性粉はほとんど身動きがとれないと予想されるので，磁性 粉に特定の樹脂からなるバインダーを添加・混合した湦練物 (コンパウンド)を用いて,バインダーの硬化・軟化を利用す ることによって成形体内部の磁性粉を配向することを考えた。 その具体的な方法は, 紫外線(UV)硬化樹脂を用いる方法 ${ }^{53}$ と MIM バインダーを用いる方法 ${ }^{54)}$ である.

UV硬化樹脂を用いる方法の場合，また着想の域を出ておら ず,これまでに得られた最大の配向度 $\mathrm{Br} / \mathrm{Js}$ は 0.83 程度で不十 分な值である. 混練物と型との離型性やUV 硬化樹脂の粘性 などに関して課題があり，現在，検討中である．なお，この 用途に用いるUV樹脂は，UV硬化だけでなく熱硬化性も兼ね 備えたタイプが適していると考えられる。一方，MIMバイン ダーを用いる場合には配向度 $\mathrm{B} r / \mathrm{Js}$ は最大で 0.95 が得られ, 型 との離型性にも問題が少ないことが明らかになっている ${ }^{54)}$. 3.4 磁性体の焼結接合

(a)ハードフェライトの焼結接合 1 つの磁性部品内におい て微結晶粒の配向方向が異なり，かつ複雑な形状を有する硬 磁性体が，制御モーター用部品などで要請深されれてい。磁 場配向プレス機によってこのような部品を一体成形しようと すると，金型の構成や配向装置が複雑になる．そこで，Fig.9 のように配向成形したインナーと無配向成形したアウターを 組み立てた後に焼結接合して一体化させる方法56-59によって， 1つの部品内で配向が異なる磁性体を作製することを考えた. この場合，ハードフェライト粉を配向成形すると焼結収縮の 異方性が生じるので，この現象を焼結ばめ効果に利用して接

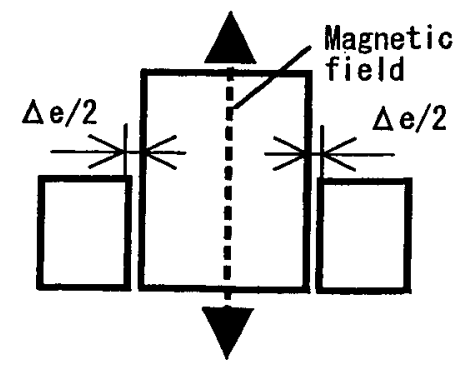

Fig.9 Combined sinter joining of ferrite compacted under magnetic field.
合強度の向上も併せて図ろうとするものである.检討の結果， 磁界配向の大きさは $250 \mathrm{kA} \cdot \mathrm{m}^{-1}$ 程度で十分であること, 組み 合わせた圧粉体を CIP処理してから $1225^{\circ} \mathrm{C} て ゙$ 焼結すると $50 \mathrm{MPa}$ 程度の接合強度が得られることが分かった。

(b)ステンレス鋼/パーマロイの焼結接合 近年における情 報技術の進展に伴い，1つの部品内で磁性 (硬磁性, 軟磁性) と非磁性を有する複合磁性体の)の用途が生じている，そのた めの具体例として，軟磁性材料の代表的なものである $\mathrm{Fe}-\mathrm{Ni}$ パーマロイとステンレス鋼との焼結接合 61,62) を行った. 供試 粉末として一般粉末治金用の -100 mesh 粗粉, MIM 用微粉お よびその造粒粉を用い, またインナーとアウターの材質の組 み合わせは Fig.10で示すAタイプとBタイプについて検討を 行い，接合強度を大きくするための適切な成形条件を調へ， 強度の形成機構について考察した。 その結果, Table 1 に示す ように十分な接合強度を得ることができた。

\section{4 結 言}

粉末を出発原料とすれば結晶組織の微細・均質化が可能で あり，粉末成形プロセスは生産工程の自動化が図りやすく材 料歩留まりがよい，そのため, 粉末成形は素形材加工におい て現在よりも重要性が增すことが期待できる. 本研究は，粉 末成形の更なる発展を期待して, 材料加工学的な観点より金 属粉の圧縮成形・加工と磁性粉の成形加工を取り扱ったもの である。一連の研究で得られた成果が, 粉末治金の拡大・発

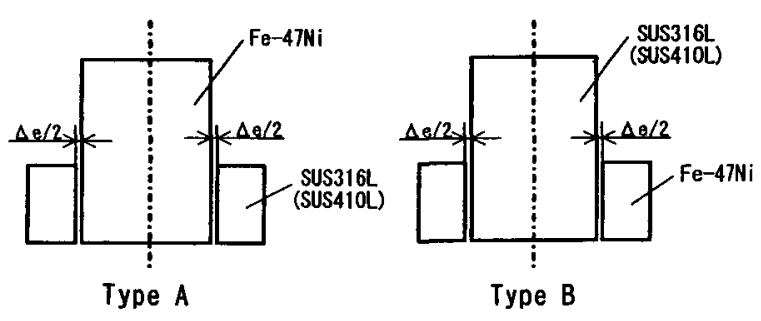

Fig.10 Fabrication of stainless steel-permalloy composite by combined sinter joining and combination of materials for inner disk and outer ring.

Table 1 Joint strength of stainless steel-permalloy composite by combined sinter joining.

(a) SUS316L $/ \mathrm{Fe}-47 \mathrm{Ni}\left(1300^{\circ} \mathrm{C} \times 1 \mathrm{~h}\right)$

\begin{tabular}{|c|c|c|}
\hline Powders & Joint strength $(\mathrm{MPa})$ & Type \\
\hline$-100 \mathrm{mesh}$ & 38 & Type A \\
\hline MIM & 263 & Type A \\
\hline Granulated & 309 & Type B \\
\hline
\end{tabular}

(b) SUS410L $/ \mathrm{Fe}-47 \mathrm{Ni}\left(1255^{\circ} \mathrm{C} \times 1 \mathrm{~h}\right)$

\begin{tabular}{|c|c|c|}
\hline Powders & Joint strength (MPa) & Type \\
\hline-100 mesh & 54 & Type A \\
\hline MIM & 155 & Type A \\
\hline Granulated & 327 & Type B \\
\hline
\end{tabular}


展に対して基礎と応用の点から多少なりとも役立つことがあ れば幸いである。

\section{謝辞}

最後に,受賞に際してお世話になりました本協会の関係者， ならびに共同研究者として協力していただきました多数の 方々に深謝します。

\section{文献}

1）中野節，堤信久，中丸善明，西村尚，浅見淳一，松野健一， 関口勇, 落合俊彦: 素形材, " 平成 12 年の素形材産業・工 学年鑑 1. 総論 ", 42(2001)2-13.

2) 例えば, R.M.German 著, 三浦秀士, 高木研一訳: 粉末冶金 の科学, 内田老鶴圈 , (1996)2-12.

3) 例えば,島進: " 粉体成形における粉体の力学的挙動に関 する研究 ", 粉体および粉末治金, 42(1995)269-276。

4)沖本邦郎, 松島峰生,萩尾剛，山川俊夫: "超音波振動を付 加した深絞り加工に関する研究", 九州工業技術試験所報 告, No.2, (1969)73-82.

5) 沖本邦郎, 山川俊夫 : "超音波を付加した鉛の中空円筒圧 縮試験について ",九州工業技術試験所報告, No.6,(1971) 307-314

6)沖本邦郎，松島峰生 : "超音波付加成形実験装置とプレス 加工 ",プレス技術, 7(1969)33-35.

7) 沖本邦郎, 山川俊夫 : "超音波のプレス加エへの応用 ", 金 属プレス, 2(1970)1-7.

8) 沖本邦郎, 山川俊夫: "超音波の利用一絞り加エー ", プレ 不技術, 9(1971)27-32.

9)冲本邦郎, 山川俊夫, 佐藤富雄: "簡易ラバープレス法に 関する実験的研究", 九州工業技術試験所報告, No.9,(1973) 506-518.

10) 近藤幹夫, 竹本患英 : " 粉末充填挙動の可視化技術 ", 粉体 および粉末治金, 45(1998)833-838.

11) M.Sagawa, H.Nagata, T.Watanabe and O.Itatani: "Rubber isostatic pressing (RIP) of powders for magnets and other materials", Mater. Design, 21(2000)243-249.

12) 冲本邦郎, 佐藤富雄, 山川俊夫: "金属粉末の側圧係数に ついて ", 粉体および粉末冶金, 22(1975)205-212.

13）沖本邦郎, 大矢根守哉, 島進 : " 金属粉末の圧縮成形に関 する研究(第 1 報) (軸対称圧縮成形の場合)",粉体および 粉末治金, 22(1975)177-184.

14）沖本邦郎, 大矢根守哉, 島進: "銅圧粉体の破買について ", 粉体および枌末治金, 22(1975)185-191.

15) 大矢根守哉, 島進, 沖本邦郎: "鉄系焼結体の延性破壞", 塑 性と加工, 20(1979)1037-1044.

16）冲本邦郎，佐藤富雄: " 金属焼結体の鐉造における再圧着 について", 九州工業技術試験所報告, No.24, (1980)14461452.

17) 沖本邦郎, 島進, 大矢根守哉: "金属圧粉体の接合 ", 塑性
と加工 , 18(1977)319-324.

18) 冲本邦郎, 大矢根守哉, 島進, 佐藤富雄, 山川俊夫: "金属 粉末成形体の圧接 ", 九州工業技術試験所報告, No.29, (1982)1900-1909.

19) 大矢根守哉, 沖本邦郎, 佐藤富雄: " 溶漫を応用した鉄系 焼結体の接合 (第 1 報)", 粉体および粉末治金 , 26(1979) 254-258.

20) 大矢根守哉, 沖本邦郎, 佐藤富雄: " 溶浸を応用した鉄系 焼結体の接合 (第 2 報)", 粉体および粉末冶金, 26(1979) 259-264.

21) 冲本邦郎, 佐藤富雄: " 溶浸を応用した鉄系焼結体の接合 (第3報)(接合強度に及ぼす溶浸温度と溶浸時間の影響)", 粉体および粉末治金, 29(1982)84-89.

22) K.Okimoto and T.Satoh: "Joining of Iron Powder Compacts by an Infiltration Method", Int. J. Powder Metall., 23(1987)163169.

23) 沖本邦郎: " 金属粉末および焼結金属の成形・破壊・接合 に関する研究 ",粉体および粉末冶金, 34(1987)51-59.

24) K.Okimoto and T.Satoh: "Compaction of $\mathrm{Zn}-22 \mathrm{Al}$ Superplastic Powder and Deformation Behaviour of the Compacts", Modern Development in Powder Metall., 16(1984)507-522.

25) K.Okimoto and T.Satoh: "Superplastic Forming of $\mathrm{Zn}$-Al Prealloy Powder", Proc. IISS Symposium (SINTERING 87), 1 (1987)611-616.

26) 佐藤富雄, 沖本邦郎, 西田稔, 今村喜八郎, 千葉昂: "超急 冷法と熱処理法による Zn-22Al 合金粉末の超塑性化の促 進 ", 粉体および粉末治金, 35(1988)91-95.

27) 佐藤富雄, 沖本邦郎, Chul-Jin Choi and Won-Wook Park: " 単ロール法と回転円盤アトマイズ法による $\mathrm{Zn}-22 \mathrm{Al}$ 急冷 凝固材の特性比較 ", 粉体および粉末治金, 38(1991)6-9.

28) 沖本邦郎, 佐藤富雄 : " 粉末法による組織微細化とその応 用 $-\mathrm{Zn}-22 \mathrm{Al}$ 合金の粉末冶金工学的研究－", 九州工業技 術試験所報告, No.52, (1994)3259-3267.

29) K.Okimoto, T.Satoh, Won-Wook Park and Young-taik Choi: "Development of fine-structured prealloy powders and their applications", Proc. 2nd Pacific Rim Int. Conf. Advanced Mater. Process., (1995)365-370.

30) 佐藤富雄, 沖本邦郎, 権田峰夫, 西田新一: "回転円盤アト マイズ法によるアルミニウム系急冷凝固粉の表面形態と 金属組織 ", 粉体および粉末治金, 41(1994)1426-1430.

31）佐藤富雄, 冲本邦郎, 安武良祐: "遠心力噴第法における 回転円盤へのセラミック溶射皮膜の適用", 溶射, 29(1992) 1-6.

32) T.Satoh, K.Okimoto and S.Nishida: "Material of Rotating Disk in Centrifugal Atomization Method", Proc. 1993 Powder Metall. World Congress, (1993)730-733.

33）佐藤富雄, 沖本邦郎, 西田新一: "遠心噴霧急冷凝固粉の 収率に及ぼす要因 ", 粉体および粉末冶金, 40(1993)11491153. 
34) Young-Taik Choi, Bong-Sun You, 佐藤富雄, 沖本邦郎: " 回 転円盤アトマイス法によるCuAINi系形状記憶合金粉とそ の焼結体の特性 ",粉体および粉末冶金, 41(1994)602-607.

35）佐藤富雄,鎌田政智，冲本邦郎: " 急冷凝固粉を用いた 2 相 ステンレス鋼の作製法",塑性と加工, 32(1991)1148-1153.

36）佐藤富雄, 沖本邦郎, 西田新一, 松木賢司, 小西義隆: " 遠 心噴霧急冷凝固法による $\mathrm{Al}-10 \% \mathrm{Mg}$ 合金粉とその押出し 材の機械的性質", 粉体および粉末冶金, 41(1994)933-938.

37) 佐藤富雄, 沖本邦郎, 西田新一：" 遠心噴第法による過共 晶AI-Si 系P/M 合金の超塑性特性", 材料, 44(1995)608-613.

38) T.Satoh, K.Okimoto, S.Nishida and K.Matsuki: "Superplasticlike behavior of rapid-solidification-processed hyper-eutectic Al-Si P/M alloys", Scr. Metall. Mater., 33(1995)819-824.

39) T.Satoh, K.Okimoto and S.Nishida: "High-temperature deformation behavior of aluminum alloys produced from centrifugally-atomized powders", J. Mater. Process. Technol., 68(1997)221-228.

40) K.Okimoto, T.Satoh, T.Yamakawa and N.Horiishi: "Composite Magnetic Compacts and Their Forming Methods", U. S. Patent, No.4, 952, 331(1990).

41) K.Okimoto, T.Satoh, T.Yamakawa and N.Horiishi: "Composite Magnetic Compacts and Their Forming Methods", U. S. Patent, No.5, 002, 727(1991).

42）冲本邦郎，佐藤富雄，堀石七生: "Zn-22A 超塑性粉末を用 いた複合磁性体 ", 粉体および粉末冶金, 35(1988)47-52.

43) K.Okimoto, T.Satoh and N.Horiishi: "Fabrication of a Magnetic Composite Material by Use of Zn-22Al Superplastic Powder", Modern Development in Powder Metall., 18(1988)799-813.

44) 沖本邦郎, 佐藤富雄, 松山博進, 岡三嘉 : "Zn-22Al 超塑性 粉末を用いた複合磁性体 (第 2 報)", 粉体および粉末治金, 38(1991)673-680.

45) 沖本邦郎, 山口勝, 佐藤富雄, 渡部正之, 堀石七生, 木下 浩光: "熱分解性バインダーを用いた異方性磁性粉末の磁 場成形", 粉体および粉末治金, 39(1992)970-976.

46) K.Okimoto, M.Yamaguchi, H.Mizue, T.Satoh, M.Watanabe, N.Horiishi and H.Kinoshita: "Orientation Forming of Ferrite Powders Using a MIM Binder", Proc. 1993 Powder Metall. World Congress, (1993)296-299.

47) 冲本邦郎, 佐藤富雄, 山口勝: "磁性粉末の配向成形に関 する研究 ", 九州工業技術試験所報告, No.51, (1993)31513171.

48) 冲本邦郎, 水江宏, 山口勝, 佐藤富雄, 渡部正之, 堀石七
生:"バインダー用ゴムを用いた異方性磁性粉末の圧延加 エ",粉体および粉末冶金, 39(1992)964-969.

49）沖本邦郎, 山口勝, 水江宏, 渡部正之, 堀石七生, 木下浩 光: "熱分解性バインダーを用いた磁性粉末の密閉型成形 と圧延加工", 塑性と加工, 34(1993)198-203.

50) 三輪茂雄 : " 粉粒体工学 ", 朝倉書店, (1972)129.

51）細川誠一,豊田幸夫, 山下治, 沖本邦郎: " $\mathrm{Sr}$ フェライトの 配向度に及ぼす粉砕粒度と成形磁場の影響", 粉体および 粉末冶金, 45(1998)77-81.

52) 細川誠一, 豊田幸夫, 沖本邦郎, 和泉克尚: " $\mathrm{Sr}$ フェライト 粉末を用いたボンド磁石の磁気特性に及ぼす成形条件の 影響 ", 粉体および粉末冶金, 46(1999)72-76。

53）沖本邦郎, 和泉克尚,豊田幸夫, 細川誠一: " 紫外線硬化樹 脂を用いた磁性粉末の配向成形",粉体および粉末冶金, 46 (1999)83-87.

54）冲本邦郎,和泉克尚,豊田幸夫, 細川誠一: "高性能配向磁 性体の新成形プロセスーMIMバインダを用いる場合ー", 平成 11 年塑性加工春季講演会論文集, (1999)269-270.

55) 例えば, 安保武志, 元根隆博: " 制御用モー夕一の界磁用 プラスチック磁石 ", 特公平 5-37330, (1993.6.2)35-41.

56) 沖本邦郎, 和泉克尚, 佐藤富雄, 豊田幸夫, 細川誠一："焼 結接合によるフェライト部品の作製", 粉体および粉末冶 金, 45(1998)763-768.

57) 神本邦郎, 和泉克尚, 豊田幸夫, 細川誠一: "Sr-フエライ 卜の収縮異方性と組み合わせ 焼結接合への応用", 粉体お よび粉末冶金 , 46(1999)67-71.

58）沖本邦郎, 和泉克尚, 豊田幸夫, 細川誠一："磁界配向した Sr-フェライト圧粉体の組み合わせ焼結接合",粉体および 粉末冶金, 47(2000)151-154.

59) K.Okimoto, K.Iwamoto, S.Toyota and S.Hosokawa: "Sinter Joining of Ferrite Compacted under Magnetic Field", Proc. 2000 Powder Metall. World Congress, Part 1, (2000)895-898.

60) 例えば, 杉山聡, 石川孝司, 中西広吉 : " 複合磁性材料の強 磁性化に及ほす加工発熱の影響 ", 塑性と加工 , 41(2000) 141-145.

61) K.Okimoto, K.Izumi, T.Satoh and Y.Kato: "Fabrication of Stainless Steel/Permalloy Alloy Composite by PM Process", Proc. 1998 Powder Metall. World Congress, 3(1998)357-362.

62) 冲本邦郎, 和泉克尚, 豊田幸夫, 細川誠一, 加藤欽之, 島 進 : "SUS316L ステンレス鋼と Fe-47Ni パーマロイの圧粉 体の組み合わせ焼結接合 ", 塑性と加工, 41(2000)11231128. 